\title{
Reaction and Characterization of Low-Temperature Effect of Transition Nanostructure Metal Codoped SCR Catalyst
}

\author{
Ke Yang, ${ }^{1}$ Weiwei Xiao, ${ }^{1}$ Quan Xu, ${ }^{1}$ Jiaojiao Bai, ${ }^{2}$ Yan Luo, ${ }^{3}$ Hao Guo, ${ }^{4}$ Li Cao, ${ }^{1}$ Wei Cai, \\ Peng Pu, ${ }^{1}$ and Lulu Cai ${ }^{2}$ \\ ${ }^{1}$ State Key Laboratory of Heavy Oil Processing, Beijing Key Laboratory of Biogas Upgrading Utilization, China University of Petroleum, \\ Beijing 102249, China \\ ${ }^{2}$ Personalized Drug Therapy Key Laboratory of Sichuan Province, Hospital of the University of Electronic Science and Technology of \\ China and Sichuan Provincial, People's Hospital, Chengdu 610072, China \\ ${ }^{3}$ Department of Chemical Engineering, West Virginia University, Morgantown, WV 26505, USA \\ ${ }^{4}$ Chongqing Institute of Forensic Science, Chongqing 400021, China
}

Correspondence should be addressed to Quan Xu; xuquan@cup.edu.cn, Peng Pu; pupeng@hotmail.fr, and Lulu Cai; lzxlulu@126.com

Received 24 January 2017; Accepted 28 February 2017; Published 20 September 2017

Academic Editor: Jinwei Gao

Copyright (C) 2017 Ke Yang et al. This is an open access article distributed under the Creative Commons Attribution License, which permits unrestricted use, distribution, and reproduction in any medium, provided the original work is properly cited.

Typical p-type semiconductor $\mathrm{MnO} x$ codoped with $\mathrm{n}$-type semiconductors such as $\mathrm{CeO}_{2}$ and $\mathrm{V}_{2} \mathrm{O}_{5}$ was reported to achieve high efficiency in catalytic $\mathrm{NO} x$ removal by $\mathrm{NH}_{3}$. In this paper, we present novel Mn-Ce codoped $\mathrm{V}_{2} \mathrm{O}_{5} / \mathrm{TiO}_{2}$ catalyst which exhibited an excellent $\mathrm{NO}$ conversion efficiency of $90 \%$ at $140^{\circ} \mathrm{C}$. By using this codoped catalyst, the best low-temperature activity was greatly decreased when compared with single $\mathrm{Mn}$ - or Ce-doped catalyst. According to the characterization results from BET, XRD, and XPS, the codoped catalyst was composed of both $\mathrm{CeO}_{2}$ and amorphous Mn. The electron circulation formed between doping elements is believed to promote the electron transfer, which may be one of the reasons for excellent low-temperature denitration performance.

\section{Introduction}

$\mathrm{NO} x$ is mainly derived from industrial emissions, traffic emissions, and living emissions. NOx gases react to form smog and acid rain as well as being central to the formation of tropospheric ozone. It especially can form small solid particles through the secondary chemical reactions that cause serious pollutions to the environment. Therefore, it is necessary to take a denitration treatment for flue gas after combustion. Selective catalytic reduction is the most widely used and effective methods for the removal of NOx in industrial at present. The main two reactions are presented in the following:

$$
\begin{array}{r}
4 \mathrm{NO}+4 \mathrm{NH}_{3}+\mathrm{O}_{2} \longrightarrow 4 \mathrm{~N}_{2}+6 \mathrm{H}_{2} \mathrm{O} \\
2 \mathrm{NO}_{2}+4 \mathrm{NH}_{3}+\mathrm{O}_{2} \longrightarrow 3 \mathrm{~N}_{2}+6 \mathrm{H}_{2} \mathrm{O}
\end{array}
$$

$\mathrm{NH}_{3}$ and $\mathrm{NO}$ almost do not react in the absence of the catalyst; therefore, the catalyst is the key for the whole reaction. $\mathrm{V}_{2} \mathrm{O}_{5} / \mathrm{TiO}_{2}$ and $\mathrm{V}_{2} \mathrm{O}_{5}-\mathrm{WO}_{3} / \mathrm{TiO}_{2}$ (anatase) catalysts operated at $350-400^{\circ} \mathrm{C}$, with less than $1 \% \mathrm{~V}_{2} \mathrm{O}_{5}$ loading, have been widely accepted as commercial catalysts [1-3]. Currently, other doped companions such as $\mathrm{Mn}, \mathrm{Cu}, \mathrm{Fe}, \mathrm{Ce}$, Wo, and F [4-8] and morphological changes in the supports can be used to modify the catalyst to achieve high catalytic activity [9-12]. W or Mo doped $\mathrm{V}_{2} \mathrm{O}_{5} / \mathrm{TiO}_{2}$, considered as the most effective commercial catalyst, is widely used for denitration in power plants and nitric acid plants $[13,14]$. However, its narrow activity temperature window forces the selective catalytic reduction (SCR) unit to be installed upstream of the desulfurizer and electrostatic precipitator where high concentrations of $\mathrm{SO}_{2}$ and particle matters can make the catalyst bed layer blocked, accelerating the deactivation of the catalyst [15]. Therefore, there is a rising interest in high 
performance catalysts that can be used at low temperature. $\mathrm{MnO} x$ has attracted significant attention because of its various types of labile oxygen species [16, 17]. Recently, Ce-doped catalyst has been found to reduce the reaction temperature significantly and has high catalytic activity and selectivity [18]. Mn-doped catalyst has shown excellent lowtemperature activity, lower apparent active energy, and better ion dispersion than those of most previously reported SCR catalysts $[17,19]$. This research committed to the development of low-temperature catalyst based on the $\mathrm{V}_{2} \mathrm{O}_{5} / \mathrm{TiO}_{2}$ and $\mathrm{V}_{2} \mathrm{O}_{5}-\mathrm{CeO}_{2} / \mathrm{TiO}_{2}$ catalyst, which is the key of the selective catalytic reduction (SCR) to remove $\mathrm{NO} x$ from effluent gas.

\section{Materials and Methods}

2.1. Materials. The low-temperature catalysts in the experiments were prepared with commercial anatase $\mathrm{TiO}_{2}$ (Tianjin Guangfu Pharmaceutical) as carriers, with a specific surface area of $7.03 \mathrm{~m}^{2} / \mathrm{g}$. Ammonium metavanadate $\left(\mathrm{NH}_{4} \mathrm{VO}_{3}\right)$ was used as the precursor of vanadium, cerium nitrate $\left(\mathrm{Ce}\left(\mathrm{NO}_{3}\right)_{3} \cdot 6 \mathrm{H}_{2} \mathrm{O}\right)$ as the precursor of cerium, and oxalic acid solution as the precursor impregnation solution in the doping process. Manganese acetate $\left(\mathrm{C}_{4} \mathrm{H}_{6} \mathrm{MnO}_{4.4} \mathrm{H}_{2} \mathrm{O}\right)$, copper nitrate $\left(\mathrm{Cu}\left(\mathrm{NO}_{3}\right)_{2.3} \mathrm{H}_{2} \mathrm{O}\right)$, cobalt nitrate $\left(\mathrm{Co}\left(\mathrm{NO}_{3}\right)_{2.6} \mathrm{H}_{2} \mathrm{O}\right)$, ferric nitrate $\left(\mathrm{Fe}\left(\mathrm{NO}_{3}\right)_{3.9} \mathrm{H}_{2} \mathrm{O}\right)$, and chromium nitrate $\left(\mathrm{Cr}\left(\mathrm{NO}_{3}\right)_{3.9} \mathrm{H}_{2} \mathrm{O}\right)$ were selected to provide $\mathrm{Mn}, \mathrm{Cu}, \mathrm{Co}, \mathrm{Fe}$, and $\mathrm{Cr}$, respectively. All these salts precursors were purchased from Tianjin Guangfu Technology Development Co., Ltd. and Aladdin Technology Co., Ltd.

2.2. Catalyst Preparation. The catalysts with different loadings of vanadium and cerium in the experiment were prepared by a conventional incipient-wetness impregnation method. Firstly, the oxalic acid was dissolved in deionized water and heated to dissolve completely, used as the precursor impregnation solution. Then, a certain quality of ammonium metavanadate was added to the oxalic acid solution and stirred until dissolved completely. A quantitative powder of cerium nitrate was added in the same way, finally, adding the $\mathrm{TiO}_{2}$ powder to the above solution, stirring, and impregnating for 1 hour. The water was evaporated from the solution by a rotary evaporator and dried at $80^{\circ} \mathrm{C}$ for 24 hours. The dried samples were calcined at $500^{\circ} \mathrm{C}$ under the air atmosphere for 2 hours. Then the catalysts were ground and sieved to 20-40 mesh for catalytic performance evaluation. Other metals like $\mathrm{Mn}, \mathrm{Fe}, \mathrm{Cr}$, etc. were doped in the same way as described above. Eventually, $\mathrm{Ce}-\mathrm{V}_{2} \mathrm{O}_{5} / \mathrm{TiO}_{2}$ catalyst with a fixed amount of $5 \%(\mathrm{wt} \%) \mathrm{V}_{2} \mathrm{O}_{5}$ but different $\mathrm{Ce}$ loadings of $5 \%, 10 \%, 15 \%, 20 \%, 25 \%$, and $30 \%(\mathrm{wt} \%)$ and other Bimetallic-doped $\mathrm{V}_{2} \mathrm{O}_{5} / \mathrm{TiO}_{2}$ catalysts were prepared by the same impregnation method [20-22]. The catalysts prepared are denoted as $x \mathrm{M}-y \mathrm{Ce}-5 \mathrm{~V}_{2} \mathrm{O}_{5} / \mathrm{TiO}_{2}$. M represents the second metal, such as $\mathrm{Mn}, \mathrm{Fe}$, or $\mathrm{Cu} ; x$ and $y$ represent the loading of $\mathrm{M}(\mathrm{wt} \%)$ and $\mathrm{Ce}(\mathrm{wt} \%)$, respectively.

2.3. Catalytic Activity Test. The SCR activity measurement was performed on a fixed-bed stainless steel tube reactor with an inner diameter of $11 \mathrm{~mm}$ and the outer diameter of $14 \mathrm{~mm}$.
Laboratory gas distribution was used to simulate the flue gas in the measurement. The feed gas mixture consisted of $\mathrm{NH}_{3} 500 \mathrm{ppm}$, NO $500 \mathrm{ppm}, 3 \% \mathrm{O}_{2}$ (volume fraction), and $\mathrm{N}_{2}$ as the balance gas. The total flow rate was $1000 \mathrm{~mL} / \mathrm{min}$ controlled by mass flow meters and the GHSV $=10,000 \mathrm{~h}^{-1}$ in each reaction. The concentrations of $\mathrm{NO} x$ were measured at the inlet and outlet by flue gas analyzer to calculate the conversion rate by the following:

$$
\begin{aligned}
\text { NO } x \text { cpnversion }(\%)= & \frac{[\mathrm{NO} x] \text { in }-[\mathrm{NO} x] \text { out }}{[\mathrm{NO} x] \text { in }} \\
& \times 100 \%
\end{aligned}
$$

where $[\mathrm{NO} x]=[\mathrm{NO}]+\left[\mathrm{NO}_{2}\right]$ and the in and out indicated the inlet and outlet concentration at steady state, respectively. The data was measured when the reaction reached the steady state (about 20-40 $\mathrm{min}$ ) at each temperature, which could reduce the errors caused by instability.

2.4. Catalyst Characterization. The powder X-ray diffraction (XRD) measurements of the samples were recorded on a Bruker D8-Advance X-ray powder diffractometer using $\mathrm{Cu}$ $\mathrm{K} \alpha$ radiation $(\lambda=1.5406 \AA)$ with scattering angles $(2 \theta)$ of $5-85^{\circ}$ and a 0.0197 step size. The specific surface areas and pore size were measured by nitrogen adsorption at $-196^{\circ} \mathrm{C}$ by the BET method using Micromeritics ASAP $2020 \mathrm{M}$ surface areas and porosity analyzer. The samples were degassed at $200^{\circ} \mathrm{C}$ for 12 hours. The X-ray photoelectron spectroscopy (XPS) experiments were carried out on a Thermo Fisher Escalab 250Xi X-ray photoelectron spectrometer system equipped with a monochromatic $\mathrm{Al} \mathrm{K \alpha} \mathrm{X}$-ray source scanning from 0 to $5000 \mathrm{eV}$.

\section{Results}

3.1. Ce-Doped Effect of $\mathrm{V}_{2} \mathrm{O}_{5}-\mathrm{TiO}_{2}$ Catalysts. NOx conversions rate at various temperatures for the $\mathrm{NH}_{3}$-SCR over Cedoped $\mathrm{V}_{2} \mathrm{O}_{5} / \mathrm{TiO}_{2}$ catalysts is shown in Figure $1 . \mathrm{V}_{2} \mathrm{O}_{5} / \mathrm{TiO}_{2}$ shows above $80 \% \mathrm{NO} x$ conversion rate at a wide temperature range of $175^{\circ} \mathrm{C}$ to $375^{\circ} \mathrm{C}$. The Ce doping can improve the catalytic activity effectively, especially from 160 to $450^{\circ} \mathrm{C}$, due to the enhancement of electron transfer rate in catalyst. The $30 \mathrm{Ce}-\mathrm{V}_{2} \mathrm{O}_{5} / \mathrm{TiO}_{2}$ shows the highest $\mathrm{NO} x$ conversion and widest temperature window with $\mathrm{NO} x$ conversion above $90 \%$ from 160 to $400^{\circ} \mathrm{C}$ and the conversion rate could reach $99.83 \%$ at $200^{\circ} \mathrm{C}$.

The catalytic activity with various Ce contents is shown in Figure 2. With the increase of Ce doping amount, the NO $x$ conversion firstly decreased and then increased at lowtemperature zone $\left(100-200^{\circ} \mathrm{C}\right)$ and high-temperature zone $\left(350-450^{\circ} \mathrm{C}\right) .10 \mathrm{Ce}-5 \mathrm{~V}_{2} \mathrm{O}_{5} / \mathrm{TiO}_{2}$ shows the worst catalytic activity, the $\mathrm{NO} x$ conversion even lower than the undoped $5 \mathrm{~V}_{2} \mathrm{O}_{5} / \mathrm{TiO}_{2}$ catalyst.

3.2. Low-Temperature Activity of $\mathrm{X}$-Ce Codoped $\mathrm{V}_{2} \mathrm{O}_{5}-\mathrm{TiO}_{2}$ Catalysts. Bimetal doped $\mathrm{V}_{2} \mathrm{O}_{5} / \mathrm{TiO}_{2}$ catalyst was prepared on the basis of single Ce-doped catalyst. The Ce loadings were selected as $30 \mathrm{wt} \%$ based on the previous results and the cometal ( $\mathrm{Mn}, \mathrm{Fe}, \mathrm{Co}, \mathrm{Cu}$, and $\mathrm{Cr}$ ) loadings were varied 


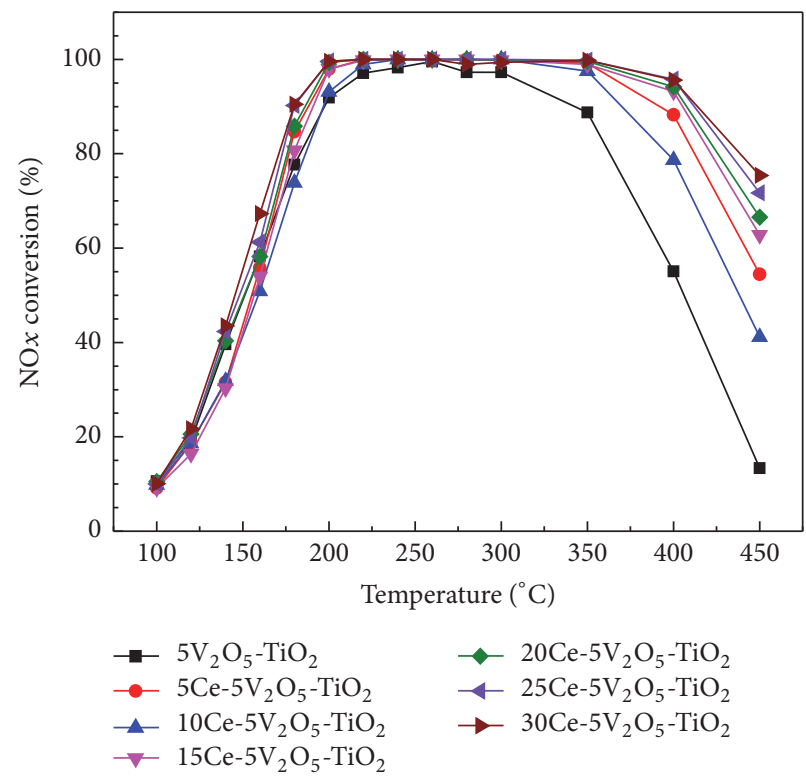

Figure 1: $\mathrm{NO} x$ conversion over Ce-doped $\mathrm{V}_{2} \mathrm{O}_{5} / \mathrm{TiO}_{2}$ catalysts with different Ce contents.
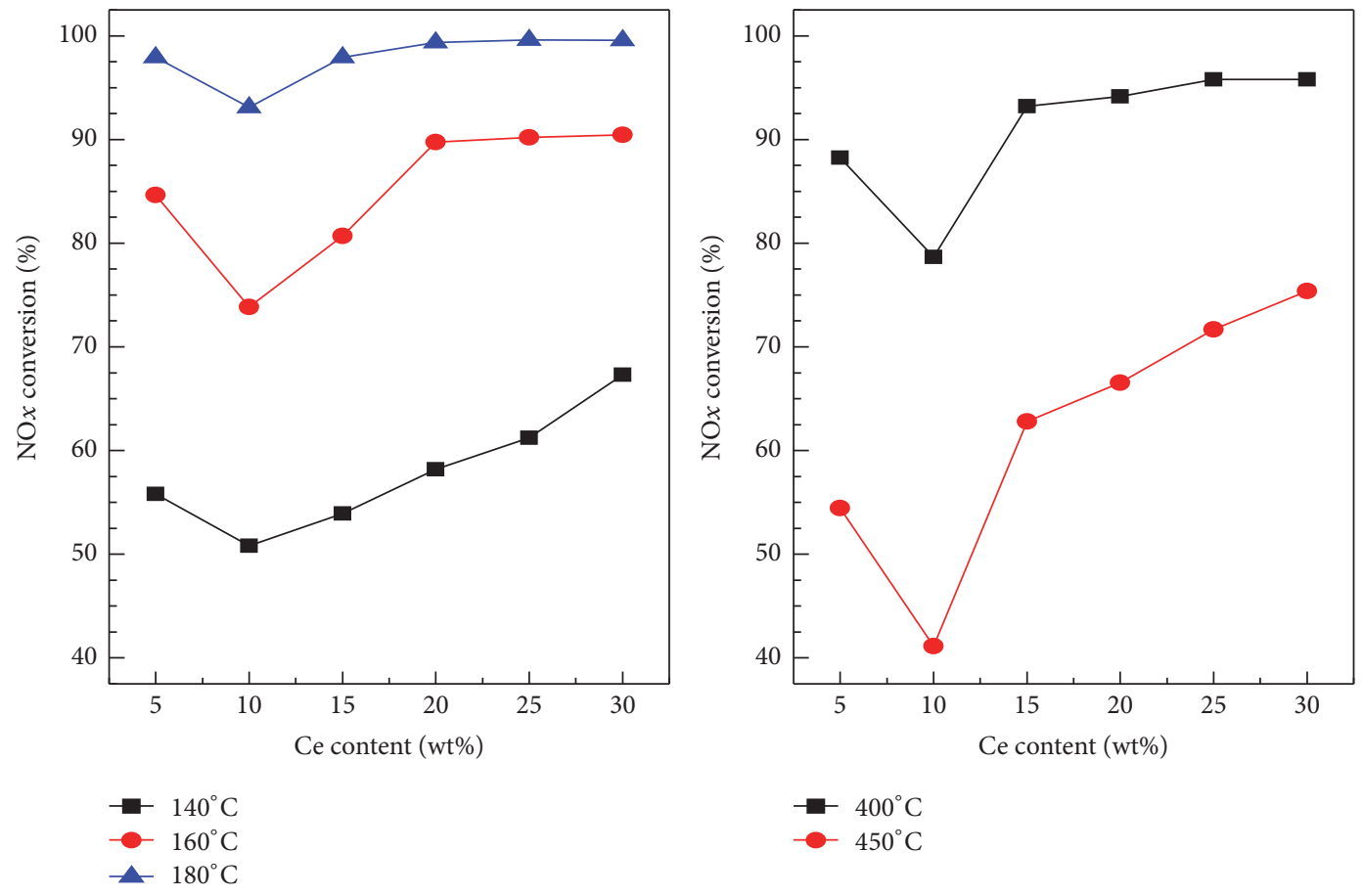

FIGURE 2: Effects of different Ce contents on NOx conversion.

ranging from 10 to $30 \mathrm{wt} \%$. The catalytic activity was tested on the fixed-bed reactor at different temperatures, and the results are shown in Figures 3 and 4. From the results we can observe that the catalytic effect of Fe-Ce codoped catalyst is slightly lower than single Ce-doped catalyst at the low-temperature zone. The $\mathrm{Cu}-\mathrm{Ce}$ codoped catalyst shows the worst activity, even less than the based $\mathrm{V}_{2} \mathrm{O}_{5} / \mathrm{TiO}_{2}$ catalyst. Co-Ce and $\mathrm{Cr}$ Ce codoped catalyst can improve the catalytic activity at the low-temperature zone but drop rapidly at high-temperatures zone. With a narrower active temperature window that cannot keep higher catalytic efficiency in a certain temperature range, $\mathrm{Mn}$-Ce codoped $\mathrm{V}_{2} \mathrm{O}_{5} / \mathrm{TiO}_{2}$ catalyst can improve the activity at low temperature effectively. It shows the best catalytic effect at low temperatures; the $\mathrm{NO} x$ conversion can reach $95.69 \%$ at $140^{\circ} \mathrm{C}$. The $20 \mathrm{Mn}-30 \mathrm{Ce}-\mathrm{V}_{2} \mathrm{O}_{5} / \mathrm{TiO}_{2}$ catalyst is the best as the effect of $20 \mathrm{Mn}-30 \mathrm{Ce}-\mathrm{V}_{2} \mathrm{O}_{5} / \mathrm{TiO}_{2}$ and $30 \mathrm{Mn}-$ $30 \mathrm{Ce}-\mathrm{V}_{2} \mathrm{O}_{5} / \mathrm{TiO}_{2}$ is almost similar.

The NOx conversion over X-Ce codoped $\mathrm{V}_{2} \mathrm{O}_{5} / \mathrm{TiO}_{2}$ catalysts with loading contents of $20 \%$ at $160^{\circ} \mathrm{C}$ is shown in Figure 5. $20 \mathrm{Mn}-30 \mathrm{Ce}-\mathrm{V}_{2} \mathrm{O}_{5} / \mathrm{TiO}_{2}$ catalyst shows the best 


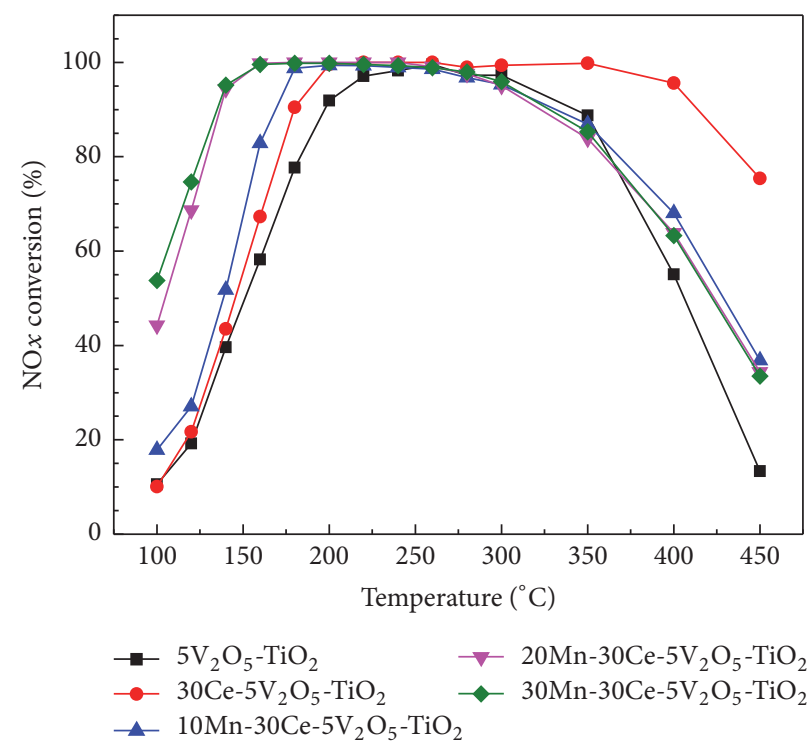

Figure 3: $\mathrm{NO} x$ conversion over $\mathrm{Mn}-\mathrm{Ce}-\mathrm{V}_{2} \mathrm{O}_{5} / \mathrm{TiO}_{2}$ catalysts with different Mn contents.

activity that the conversion rate can reach $99.58 \%$ which is nearly $30 \%$ higher than singer Ce-doped. The catalytic activity over X-Ce codoped $\mathrm{V}_{2} \mathrm{O}_{5} / \mathrm{TiO}_{2}$ catalysts is in the order of $\mathrm{Mn}-\mathrm{Ce}>\mathrm{Co}-\mathrm{Ce}>\mathrm{Cr}-\mathrm{Ce}>\mathrm{Ce}>\mathrm{Fe}-\mathrm{Ce}>\mathrm{Cu}-\mathrm{Ce}$ codoped.

3.3. Mn-Ce Codoped Effect. Initially, the single $\mathrm{Mn}$ - and Cedoped $\mathrm{V}_{2} \mathrm{O}_{5} / \mathrm{TiO}_{2}$ catalysts are prepared by the impregnation method to investigate the effect of single $\mathrm{Mn}$ or $\mathrm{Ce}$, as compared to the $\mathrm{Mn}$-Ce codoped catalyst. The result is shown in Figure 6. The NOx conversion over $\mathrm{Mn}-\mathrm{Ce}$ codoped $\mathrm{V}_{2} \mathrm{O}_{5} / \mathrm{TiO}_{2}$ catalyst can reach more than $90 \%$ at $140^{\circ} \mathrm{C}$, which is much higher than single doped catalyst. $\mathrm{Mn}$-Ce codoped $\mathrm{V}_{2} \mathrm{O}_{5} / \mathrm{TiO}_{2}$ catalysts have the best low-temperature activity that can drop to $80^{\circ} \mathrm{C}$ which is lower than $\mathrm{Mn}$-doped catalyst and Ce-doped catalyst. However, the catalytic activity is difficult to maintain at high temperature. Single Ce-doped catalyst has the widest temperature window, but the lowtemperature effect is not obvious. Mn-doped catalyst has neither good low-temperature activity nor wide temperature window. Relevant characterizations have been taken to the three kinds of catalysts in this experiment.

3.4. XRD. The X-ray powder diffraction patterns of the $\mathrm{Mn}$-Ce codoped and single $\mathrm{Ce}$ - and $\mathrm{Mn}$-doped $\mathrm{V}_{2} \mathrm{O}_{5} / \mathrm{TiO}_{2}$ catalysts are shown in Figure 7. All the reflections provide typical diffraction patterns for the $\mathrm{TiO}_{2}$ anatase phase. The characteristic peaks of $\mathrm{Ce}$ and $\mathrm{Mn}$ oxides appear, respectively, in single $\mathrm{Ce}$ - and $\mathrm{Mn}$-doped catalyst. In the pattern of $30 \mathrm{Ce}-\mathrm{V}_{2} \mathrm{O}_{5} / \mathrm{TiO}_{2}$, the doped $\mathrm{Ce}$ exists mainly in the form of $\mathrm{CeO}_{2}$ and part of $\mathrm{CeVO}_{4}$. It was found that $\mathrm{CeO}_{2}$ can effectively improve the catalytic activity and make the reaction temperature window wider [18]. However, the formation of $\mathrm{CeVO}_{4}$ has a certain suppression to the improvement of catalytic activity [23]. A variety of diffraction peaks of $\mathrm{Mn}$ oxides appeared in the single Mn-doped catalyst, including $\mathrm{Mn}_{2} \mathrm{O}_{3}, \mathrm{Mn}_{3} \mathrm{O}_{4}$, and $\mathrm{MnO}_{2}$. With the codoping of $\mathrm{Mn}-\mathrm{Ce}$, the diffraction peaks of $\mathrm{TiO}_{2}$ become weak significantly and
$\mathrm{CeO}_{2}$ crystal phase appears, but much weaker than single Cedoped catalyst. The XRD results show that $\mathrm{Mn}, \mathrm{Ce}$, and $\mathrm{TiO}_{2}$ have displayed a mutual influence by the codoping of $\mathrm{Mn}-\mathrm{Ce}$. The incorporation of $\mathrm{Mn}$ makes Ce exist in the form of $\mathrm{CeO}_{2}$, but $\mathrm{Mn}$ is mostly in the amorphous state which can achieve a better low-temperature effect.

3.5. BET. The results of BET surface area, pore volume, and average pore diameter of each catalyst are shown in Table 1. Ce has a large particle diameter that the incorporation of Ce can improve the BET surface area effectively which is nearly five times more than original $\mathrm{V}_{2} \mathrm{O}_{5}-\mathrm{TiO}_{2}$. Only a slight increase of the BET surface area has been achieved by the incorporation of Mn. But Mn-Ce codoped catalyst has the maximum surface area and minimum pore size. The change of BET surface area is consistent with the catalytic performance evaluation results in Figure 6.

3.6. XPS. The XPS spectra of Ce $3 \mathrm{~d}$ of Mn-Ce codoped and single Ce-doped $\mathrm{V}_{2} \mathrm{O}_{5} / \mathrm{TiO}_{2}$ catalyst are shown in Figure 8 . The spectrum of $\mathrm{Ce} 3 \mathrm{~d}$ contains eight peaks, in which $u$, $u^{\prime \prime}, u^{\prime \prime \prime}, v, v^{\prime \prime}$, and $v^{\prime \prime \prime}$ are the characteristic peaks of $\mathrm{Ce}^{4+}$ and $u^{\prime}$ and $v^{\prime}$ are the characteristic peaks of $\mathrm{Ce}^{3+}$. According to the intensity of the peak, Ce mainly exists as $\mathrm{Ce}^{4+}$ in both Mn-Ce codoped and single Ce-doped catalyst. The incorporation of $\mathrm{Mn}$ impacts the surface valence distribution of $\mathrm{Ce}$ that the $\mathrm{Ce}^{4+}$ increases significantly and $\mathrm{Ce}^{3+}$ reduces accordingly. The relative surface concentration of $\mathrm{Ce}^{4+}$ and $\mathrm{Ce}^{3+}$ calculated by the peak area is shown in Figure 9. The ratio of $\mathrm{Ce}^{4+} /\left(\mathrm{Ce}^{3+}+\mathrm{Ce}^{4+}\right)$ increased from $85 \%$ to $88.87 \%$ for $\mathrm{Ce}-\mathrm{V}_{2} \mathrm{O}_{5} / \mathrm{TiO}_{2}$ and $\mathrm{Mn}$-doped $\mathrm{Ce}-\mathrm{V}_{2} \mathrm{O}_{5} / \mathrm{TiO}_{2}$ catalysts, respectively. These results suggest that the incorporation of $\mathrm{Mn}$ can convert part of the $\mathrm{Ce}^{3+} \mathrm{Ce}^{4+}$ and increase the proportion of $\mathrm{Ce}^{4+}$.

The XPS spectra of Mn 2p of Mn-Ce codoped and single $\mathrm{Mn}$-doped $\mathrm{V}_{2} \mathrm{O}_{5} / \mathrm{TiO}_{2}$ catalyst are shown in Figure 10. Mn 2p 

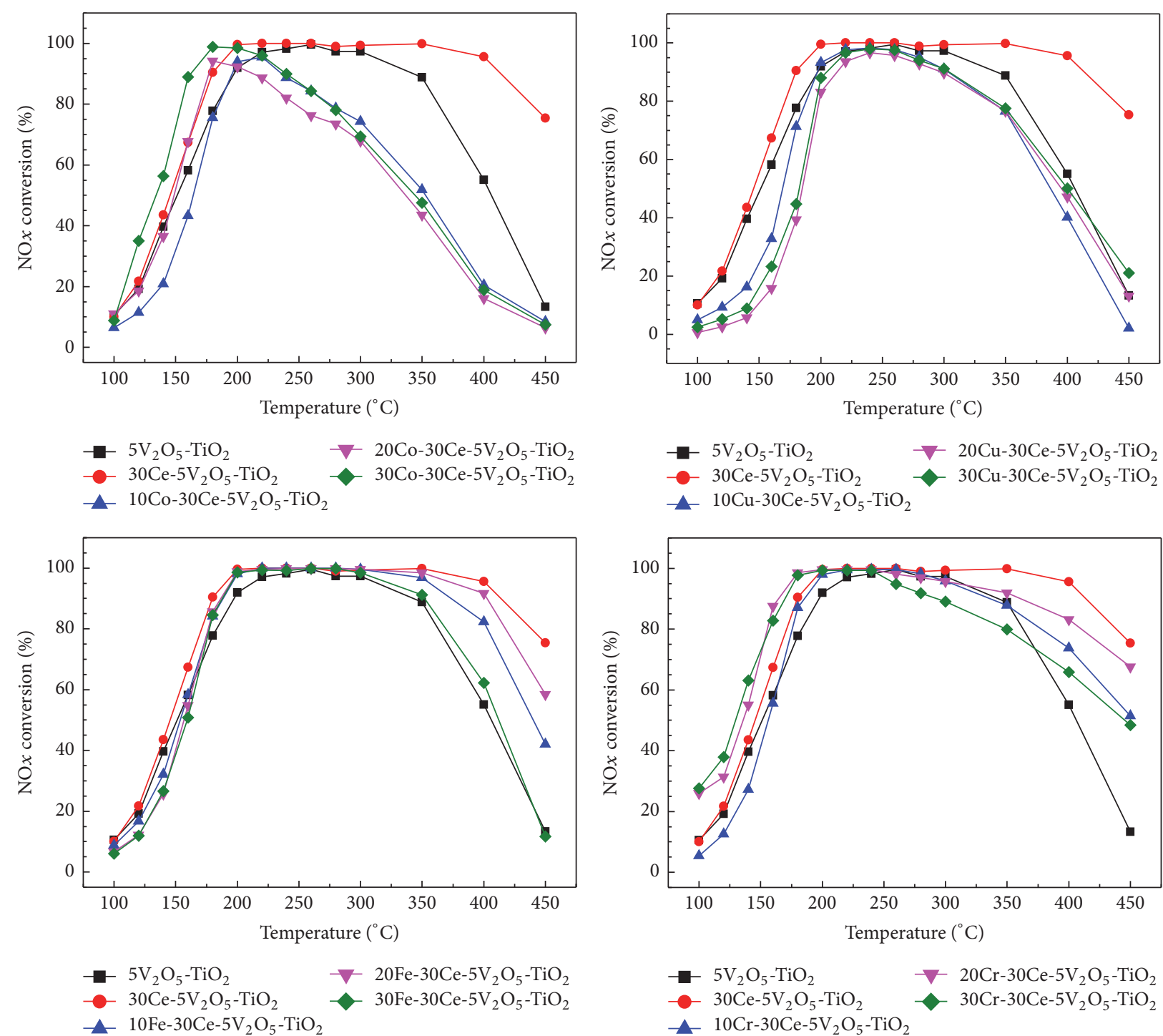

Figure 4: NOx conversion over Co-30Ce, Cu-30Ce, Fe-30Ce, and $\mathrm{Cr}-30 \mathrm{Ce}$ codoped $\mathrm{V}_{2} \mathrm{O}_{5} / \mathrm{TiO}_{2}$ catalysts with different $\mathrm{Co}$, Cu, $\mathrm{Fe}$, and $\mathrm{Cr}$ loading contents.

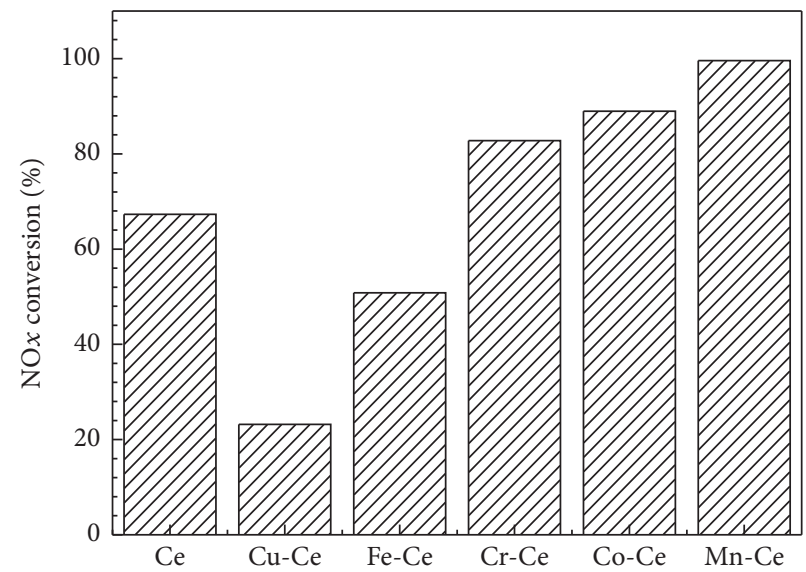

Figure 5: $\mathrm{NO} x$ conversion over $\mathrm{X}$-Ce codoped $\mathrm{V}_{2} \mathrm{O}_{5} / \mathrm{TiO}_{2}$ catalysts with different loading metals at $160^{\circ} \mathrm{C}$. 


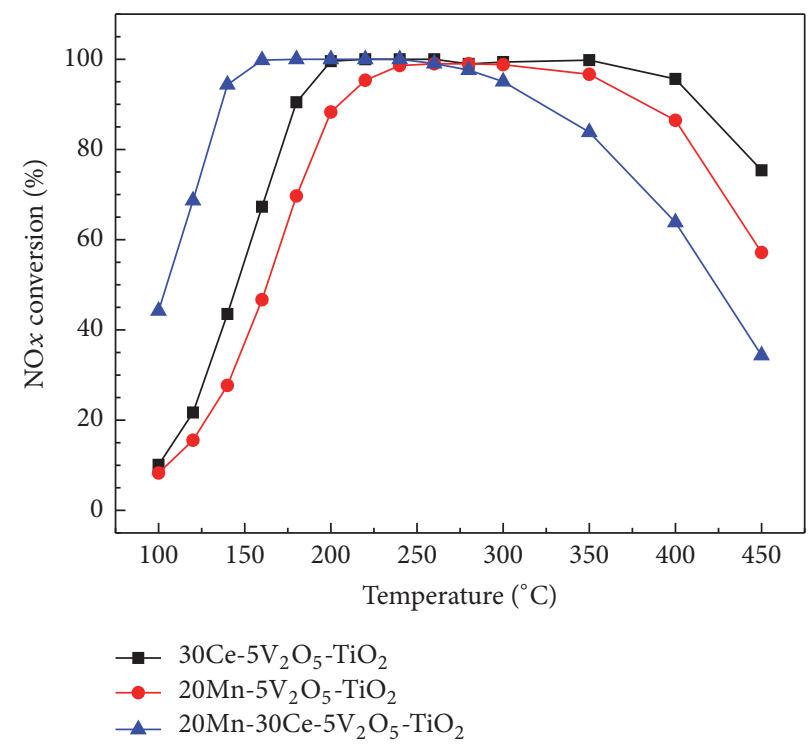

Figure 6: $\mathrm{NO} x$ conversion over $20 \mathrm{Mn}-30 \mathrm{Ce}-5 \mathrm{~V}_{2} \mathrm{O}_{5} / \mathrm{TiO}_{2}, 30 \mathrm{Ce}-5 \mathrm{~V}_{2} \mathrm{O}_{5} / \mathrm{TiO}_{2}$, and $20 \mathrm{Mn}-5 \mathrm{~V}_{2} \mathrm{O}_{5} / \mathrm{TiO}_{2}$ catalysts.

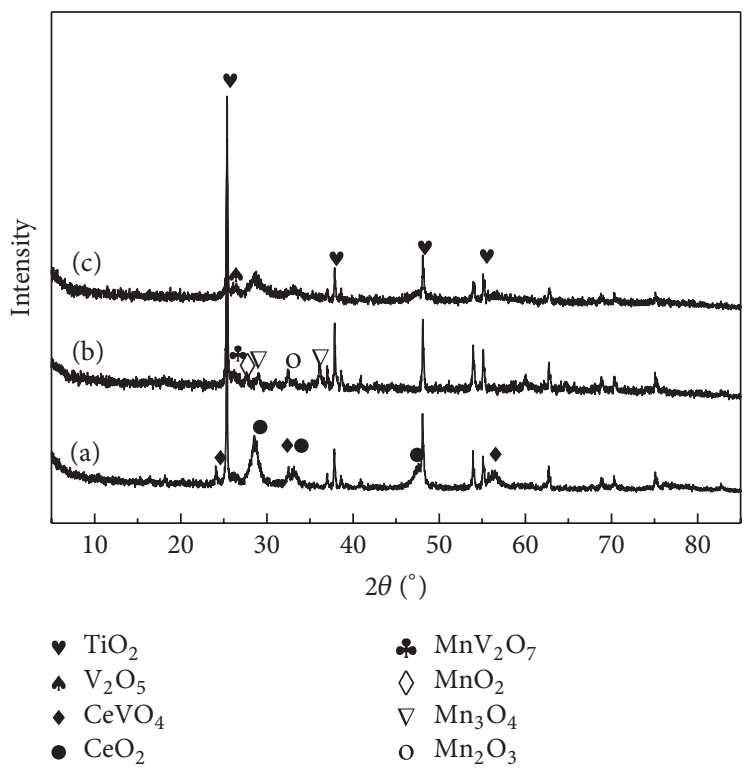

FIgUre 7: XRD profiles of (a) Ce-doped, (b) Mn-doped, and (c) Mn-Ce codoped $\mathrm{V}_{2} \mathrm{O}_{5} / \mathrm{TiO}_{2}$ catalysts.

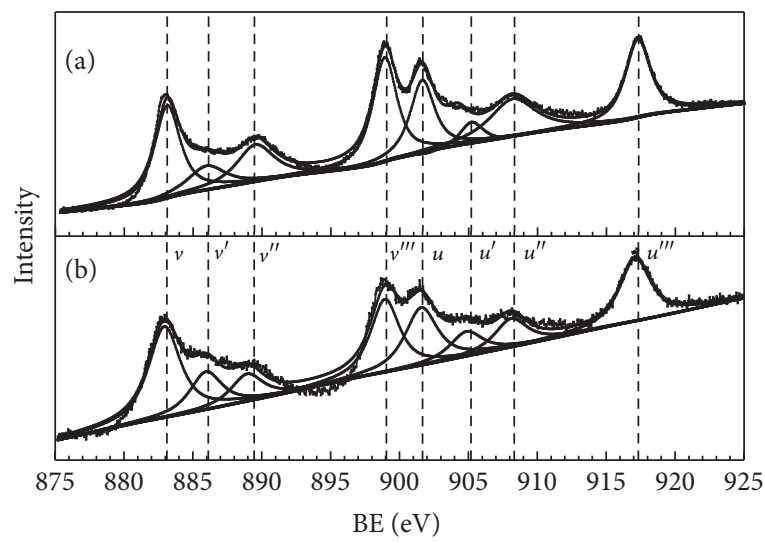

Figure 8: XPS spectra of Ce 3d of (a) $\mathrm{Mn}-\mathrm{Ce}-\mathrm{V}_{2} \mathrm{O}_{5} / \mathrm{TiO}_{2}\left(20 \mathrm{Mn}-30 \mathrm{Ce}\right.$ ) and (b) $\mathrm{Ce}-\mathrm{V}_{2} \mathrm{O}_{5} / \mathrm{TiO}_{2}(30 \mathrm{Ce}$ ) catalysts. 
TABLE 1: Comparison of BET surface area, pore volume, and average pore diameter.

\begin{tabular}{lccc}
\hline Samples & BET surface area $\left(\mathrm{m}^{2} / \mathrm{g}\right)$ & Pore volume $\left(\mathrm{cm}^{3} / \mathrm{g}\right)$ & Average pore diameter $(\mathrm{nm})$ \\
\hline $\mathrm{V}_{2} \mathrm{O}_{5}-\mathrm{TiO}_{2}$ & 5.5022 & 0.025621 & 186.2567 \\
$\mathrm{Ce}-\mathrm{V}_{2} \mathrm{O}_{5}-\mathrm{TiO}_{2}$ & 28.7009 & 0.141243 & 196.8476 \\
$\mathrm{Mn}^{-} \mathrm{V}_{2} \mathrm{O}_{5}-\mathrm{TiO}_{2}$ & 8.9057 & 0.061350 & 271.3350 \\
$\mathrm{Mn}-\mathrm{Ce}-\mathrm{V}_{2} \mathrm{O}_{5}-\mathrm{TiO}_{2}$ & 33.5854 & 0.125967 & 150.0261 \\
\hline
\end{tabular}

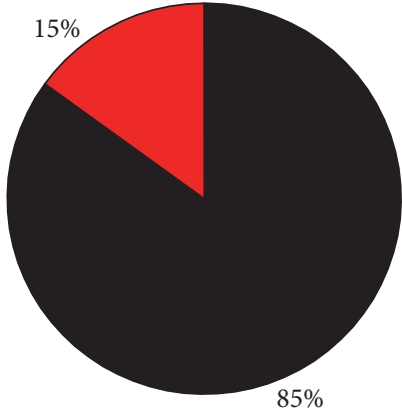

$\mathrm{Ce}^{4+}$
$\square \mathrm{Ce}^{3+}$

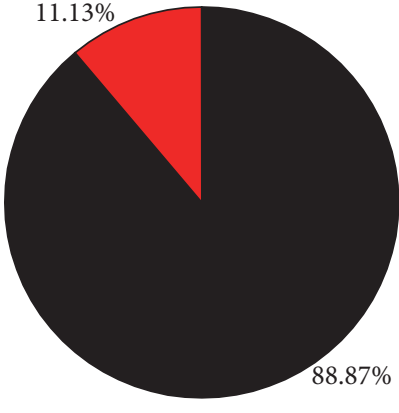

$\mathrm{Ce}^{4+}$

(a)

(b)

Figure 9: Surface atomic concentration ratio of $\mathrm{Ce}^{3+}$ and $\mathrm{Ce}^{4+}$. (a) $30 \mathrm{Ce}-5 \mathrm{~V}_{2} \mathrm{O}_{5} / \mathrm{TiO}_{2}$ and (b) $20 \mathrm{Mn}-30 \mathrm{Ce}-5 \mathrm{~V}_{2} \mathrm{O}_{5} / \mathrm{TiO}_{2}$.

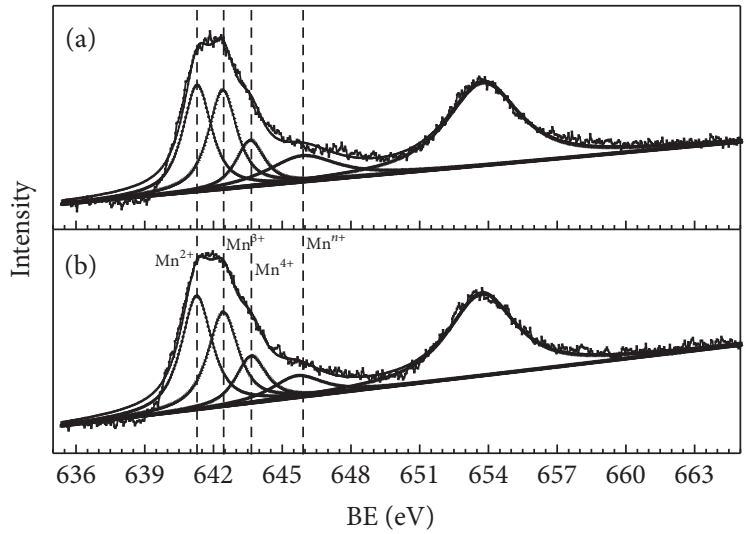

Figure 10: XPS spectra of Mn 2p of (a) Mn-Ce- $\mathrm{V}_{2} \mathrm{O}_{5} / \mathrm{TiO}_{2}\left(20 \mathrm{Mn}-30 \mathrm{Ce}\right.$ ) and (b) $\mathrm{Mn}-\mathrm{V}_{2} \mathrm{O}_{5} / \mathrm{TiO}_{2}(20 \mathrm{Mn}$ ) catalysts.

has two main peaks, Mn 2p1/2 (near $654 \mathrm{eV}$ ) and Mn 2p3/2 (near $642 \mathrm{eV}$ ), respectively. The characteristic peak of $\mathrm{Mn}$ $2 \mathrm{p} 3 / 2$ is superimposed from four peaks of Mn with different valence. Divide the characteristic peak into four subpeaks that $\mathrm{Mn}^{2+}(641.2-641.5 \mathrm{eV}), \mathrm{Mn}^{3+}(642.3-642.5 \mathrm{eV}), \mathrm{Mn}^{4+}$ $(643.5-643.8 \mathrm{eV})$, and $\mathrm{Mn}^{n+}(645.8-646.0 \mathrm{eV})$ can be achieved. The relative surface concentration of $\mathrm{Mn}^{2+}, \mathrm{Mn}^{3+}$, and $\mathrm{Mn}^{4+}$ calculated by the peak area is shown in Figure 11. Mn mostly exists in the form of $\mathrm{Mn}^{2+}$ in both $\mathrm{Mn}-\mathrm{Ce}$ codoped and single Mn-doped catalyst. The higher the valence, the lower the atomic concentration. Under the interaction in Mn-Ce codoped system, a small part of the lowvalence $\mathrm{Mn}^{2+}$ is oxidized to $\mathrm{Mn}^{3+}$. The incorporation of $\mathrm{Mn}$ can react with Ce which has a variable valence that can promote the electron transfer between active components. Some chemical reactions may occur between the $\mathrm{Mn}^{2+}$ and $\mathrm{Ce}^{4+}$ as the following:

$$
\begin{aligned}
& \mathrm{Mn}^{2+}+\mathrm{Ce}^{4+} \longrightarrow \mathrm{Mn}^{3+}+\mathrm{Ce}^{3+} \\
& 2 \mathrm{Ce}^{3+}+\frac{1}{2} \mathrm{O}_{2} \longrightarrow 2 \mathrm{Ce}^{4+}+\mathrm{O}^{2-}
\end{aligned}
$$

The XPS spectra of V 2p of Mn-Ce codoped and single $\mathrm{Ce}$ - and $\mathrm{Mn}$-doped $\mathrm{V}_{2} \mathrm{O}_{5} / \mathrm{TiO}_{2}$ catalyst are shown in Figure 12. The characteristic peak of V2p3/2 appears within 515 $518 \mathrm{eV}$, which can be divided into two peaks, $\mathrm{V}^{4+}(516.7 \mathrm{eV})$ and $\mathrm{V}^{5+}(517.6 \mathrm{eV})$. The relative surface concentration of $\mathrm{V}^{4+}$ and $\mathrm{V}^{5+}$ calculated by the peak area is shown in Figure 13 . The concentration of $\mathrm{V}^{5+}$ in a descending order of $\mathrm{Mn}-\mathrm{Ce}$ codoped $>\mathrm{Ce}$-doped $>\mathrm{Mn}$-doped. $\mathrm{V}^{5+}$ is the active center of 

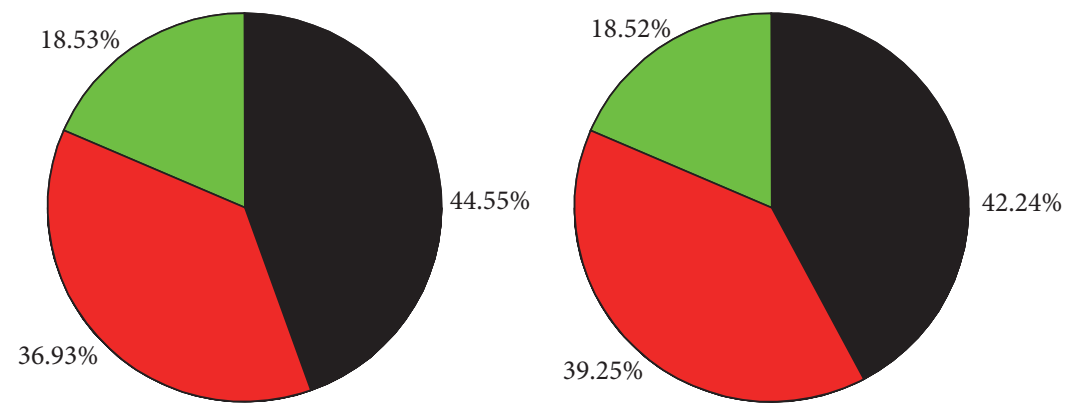

$$
\begin{aligned}
& \mathrm{Mn}^{2+} \\
& \mathrm{Mn}^{3+} \\
& \mathrm{Mn}^{4+}
\end{aligned}
$$

$\mathrm{Mn}^{2+}$

$\square \mathrm{Mn}^{3+}$

$\square \mathrm{Mn}^{4+}$

(a)

(b)

Figure 11: Surface atomic concentration ratio of of $\mathrm{Mn}^{2+}, \mathrm{Mn}^{3+}$, and $\mathrm{Mn}^{4+}$. (a) $\mathrm{Mn}-\mathrm{V}_{2} \mathrm{O}_{5} / \mathrm{TiO}_{2}$ and (b) $\mathrm{Mn}-\mathrm{Ce}-\mathrm{V}_{2} \mathrm{O}_{5} / \mathrm{TiO}{ }_{2}$.

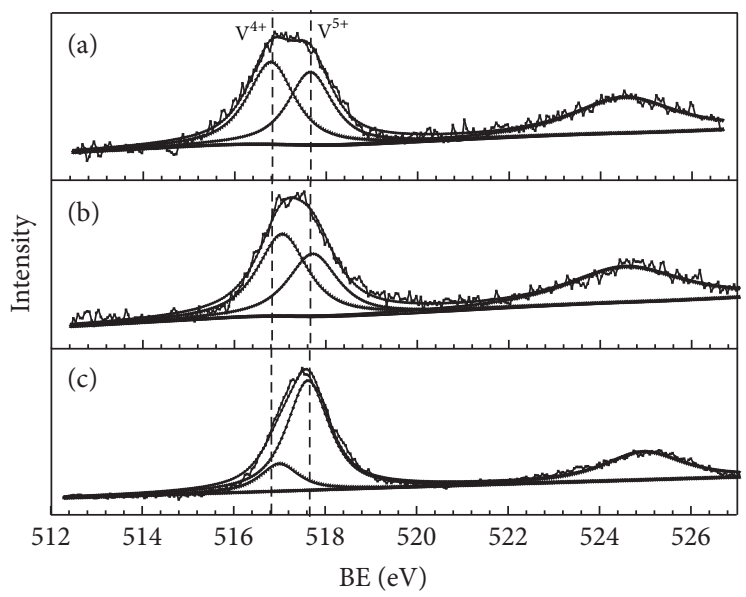

Figure 12: XPS spectra of V 2p of (a) $30 \mathrm{Ce}-5 \mathrm{~V}_{2} \mathrm{O}_{5} / \mathrm{TiO}_{2}$ (30Ce), (b) $20 \mathrm{Mn}-5 \mathrm{~V}_{2} \mathrm{O}_{5} / \mathrm{TiO}_{2}(20 \mathrm{Mn})$, and (c) $20 \mathrm{Mn}-30 \mathrm{Ce} 5 \mathrm{~V}_{2} \mathrm{O}_{5} / \mathrm{TiO} 2(20 \mathrm{Mn}-$ 30Ce) catalysts.

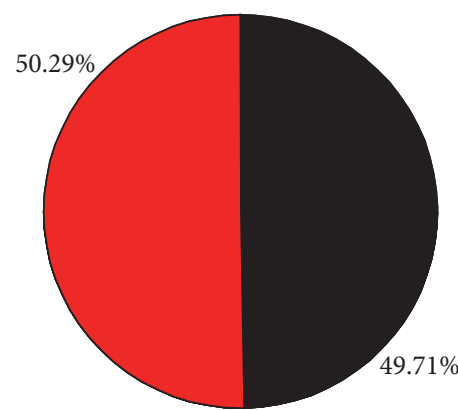

$\mathrm{V}^{4+}$

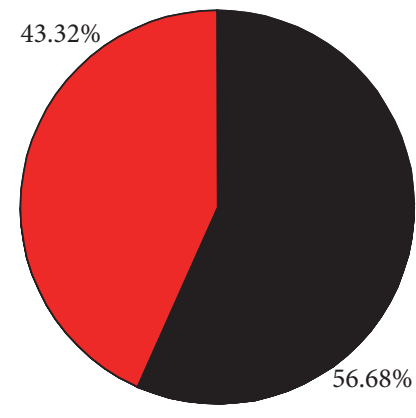

$\mathrm{V}^{4+}$
$\mathrm{V}^{5+}$

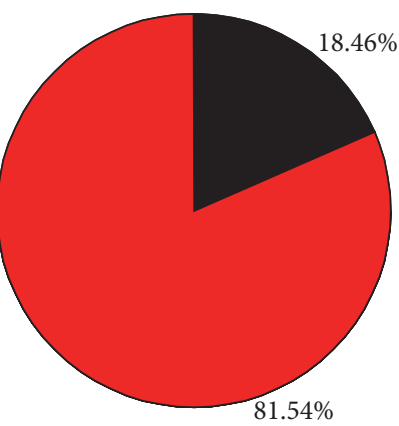

$\mathrm{V}^{4+}$

(a)

(b)

(c)

FIGURE 13: Surface atomic concentration ratio of $\mathrm{V}^{4+}$ and $\mathrm{V}^{5+}$. (a) $20 \mathrm{Mn}-5 \mathrm{~V}_{2} \mathrm{O}_{5} / \mathrm{TiO}_{2}$, (b) $30 \mathrm{Ce}-5 \mathrm{~V}_{2} \mathrm{O}_{5} / \mathrm{TiO}_{2}$, and (c) $20 \mathrm{Mn}-30 \mathrm{Ce}-$ $5 \mathrm{~V}_{2} \mathrm{O}_{5} / \mathrm{TiO}_{2}$. 
the denitration catalyst and $\mathrm{NO}$ and $\mathrm{NH}_{3}$ can easily adsorb on the $\mathrm{V}^{5+}$ centers that promote the oxidation and reduction of NO. Under the coeffect of $\mathrm{Mn}$ and $\mathrm{Ce}$, a lot of $\mathrm{V}^{4+}$ convert into more active $\mathrm{V}^{5+}$; the concentration of $\mathrm{V}^{5+}$ increased more than $30 \%$.

The XPS results show that the Mn-Ce codoped catalysts promote the interaction among $\mathrm{Mn}, \mathrm{Ce}$, and $\mathrm{V}$. The three kinds of atoms are moving to higher valence direction, which is benefical for elcetron transformation and oxidation ability of the whole catalytic system. This is more conducive to the $\mathrm{NOx}$ reduced by $\mathrm{HN} 3$ at low temperatures.

\section{Conclusions}

Typical p-type semiconductor $\mathrm{MnO} x$ codoped with $\mathrm{n}$ type semiconductors such as $\mathrm{CeO}_{2}$ and $\mathrm{V}_{2} \mathrm{O}_{5}$ achieved the excellent effect on $\mathrm{NO}$ removal by $\mathrm{NH}_{3}$. Mn-Ce codoped vanadium-titanium catalyst system can effectively lower the reaction temperature and improve the efficiency. The NOx conversion over $\mathrm{Mn}$-Ce codoped $\mathrm{V}_{2} \mathrm{O}_{5} / \mathrm{TiO}_{2}$ catalyst can reach more than $90 \%$ at $140^{\circ} \mathrm{C}$ that is much higher than single doped catalyst. Mn-Ce codoped $\mathrm{V}_{2} \mathrm{O}_{5} / \mathrm{TiO}_{2}$ catalyst has the best low-temperature activity that can drop to $80^{\circ} \mathrm{C}$ which is lower than single $\mathrm{Mn}$-doped catalyst and Ce-doped catalyst. The codoping of $\mathrm{Mn}$-Ce makes Ce exist in the form of $\mathrm{CeO}_{2}$, but $\mathrm{Mn}$ is mostly in amorphous state on the surface which can achieve better low-temperature effect. The incorporation of $\mathrm{Mn}$ can react with $\mathrm{Ce}$ which has a variable valence that can promote the electron transfer between the two active components to form an effective electron circulation in the presence of oxygen. The $\mathrm{Mn}, \mathrm{Ce}$, and $\mathrm{V}$ are moving to higher valence direction that the oxidation increased, which is more conducive to the $\mathrm{NO}_{X}$ reduced by $\mathrm{NH}_{3}$. Thus even at low temperatures, it is possible to release $\mathrm{O}$ radical in the process of $\mathrm{NO}$ adsorption, which can be oxidized to $\mathrm{NO}_{2}$ and then react with $\mathrm{NH}_{3}$. All in all, Mn-Ce codoped $\mathrm{V}_{2} \mathrm{O}_{5} / \mathrm{TiO}_{2}$ catalyst utilizes the electron transfer between $\mathrm{Mn}, \mathrm{Ce}$, and $\mathrm{V}$ effectively, and the denitration performance at low temperature is greatly improved. This finding may help scientists and engineers to development next generation smart surfaces $[24,25]$ with absorption functionality.

\section{Conflicts of Interest}

The authors declare that they have no conflicts of interest.

\section{Authors' Contributions}

Quan Xu, Peng Pu, and Li Cao conceived and designed the experiments; Ke Yang and Weiwei Xiao performed the experiments; Jiaojiao Bai, Li Cao, Yan Luo, and Hao Guo analyzed the data; Wei Cai contributed reagents/materials/analysis tools; Peng Pu and Quan Xu wrote the paper.

\section{Acknowledgments}

The authors thank Beijing Municipal Science and Technology Project (nos. Z161100001316010 and D141100002814001), National Key Research and Development Plan (no. 2016YFC0303701), Tribology Science Fund of State Key
Laboratory of Tribology (no. SKLTKF16A06), and Science Foundation of China University of Petroleum (nos. 2462014YJRC011, ZX20160056, and 201603) for the support.

\section{References}

[1] R. M. Heck, "Catalytic abatement of nitrogen oxides-stationary applications," Catalysis Today, vol. 53, no. 4, pp. 519-523, 1999.

[2] S. C. Wood, "Select the right IMOx control technology," Chemical Engineering Progress. Energy Technology Consultants, p. 33, 1994.

[3] M. F. H. Van Tol, M. A. Quinlan, F. Luck, G. A. Somorjai, and B. E. Nieuwenhuys, "The catalytic reduction of nitric oxide by ammonia over a clean and vanadium oxide-coated platinum foil," Journal of Catalysis, vol. 129, no. 1, pp. 186-194, 1991.

[4] L. Chmielarz, P. Kuśtrowski, R. Dziembaj, P. Cool, and E. F. Vansant, "Catalytic performance of various mesoporous silicas modified with copper or iron oxides introduced by different ways in the selective reduction of NO by ammonia," Applied Catalysis B: Environmental, vol. 62, no. 3-4, pp. 369-380, 2006.

[5] Q. Li, H. Yang, F. Qiu, and X. Zhang, "Promotional effects of carbon nanotubes on $\mathrm{V}_{2} \mathrm{O}_{5} / \mathrm{TiO}_{2}$ for $\mathrm{NO}_{X}$ removal," Journal of Hazardous Materials, vol. 192, no. 2, pp. 915-921, 2011.

[6] P. S. Metkar, M. P. Harold, and V. Balakotaiah, "Selective catalytic reduction of $\mathrm{NOx}$ on combined $\mathrm{Fe}$-and $\mathrm{Cu}$-zeolite monolithic catalysts: sequential and dual layer configurations," Applied Catalysis B: Environmental, vol. 111, pp. 67-80, 2012.

[7] X. Wu, Z. Si, G. Li, D. Weng, and Z. Ma, "Effects of cerium and vanadium on the activity and selectivity of $\mathrm{MnO}_{x}-\mathrm{TiO}_{2}$ catalyst for low-temperature NH3-SCR," Journal of Rare Earths, vol. 29, no. 1, pp. 64-68, 2011.

[8] Z. Wu, R. Jin, H. Wang, and Y. Liu, "Effect of ceria doping on $\mathrm{SO}_{2}$ resistance of $\mathrm{Mn} / \mathrm{TiO}_{2}$ for selective catalytic reduction of $\mathrm{NO}$ with $\mathrm{NH}_{3}$ at low temperature," Catalysis Communications, vol. 10, no. 6, pp. 935-939, 2009.

[9] M. Kang, J. Choi, Y. T. Kim et al., "Effects of preparation methods for $\mathrm{V}_{2} \mathrm{O}_{5}-\mathrm{TiO}_{2}$ aerogel catalysts on the selective catalytic reduction of $\mathrm{NO}$ with $\mathrm{NH}_{3}$," Korean Journal of Chemical Engineering, vol. 26, no. 3, pp. 884-889, 2009.

[10] L. Xiong, Q. Zhong, Q. Chen, and S. Zhang, " $\mathrm{TiO}_{2}$ nanotubesupported $\mathrm{V}_{2} \mathrm{O}_{5}$ catalysts for selective $\mathrm{NO}$ reduction by $\mathrm{NH}_{3}$," Korean Journal of Chemical Engineering, vol. 30, no. 4, pp. 836841, 2013.

[11] Q. Li, X. Hou, H. Yang et al., "Promotional effect of $\mathrm{CeO}$ X for $\mathrm{NO}$ reduction over $\mathrm{V}_{2} \mathrm{O}_{5} / \mathrm{TiO}_{2}$-carbon nanotube composites," Journal of Molecular Catalysis A: Chemical, vol. 356, pp. 121-127, 2012.

[12] J. Li, H. Chang, L. Ma, J. Hao, and R. T. Yang, "Low-temperature selective catalytic reduction of $\mathrm{NO}_{x}$ with $\mathrm{NH}_{3}$ over metal oxide and zeolite catalysts-a review," Catalysis Today, vol. 175, no. 1, pp. 147-156, 2011.

[13] J. M. García-Cortés, J. Pérez-Ramírez, M. J. Illán-Gómez, F. Kapteijn, J. A. Moulijn, and C. Salinas-Martínez de Lecea, "Comparative study of Pt-based catalysts on different supports in the low-temperature de-NOx-SCR with propene," Applied Catalysis B: Environmental, vol. 30, no. 3-4, pp. 399-408, 2001.

[14] H. Xu, Z. Qu, C. Zong, F. Quan, J. Mei, and N. Yan, "Catalytic oxidation and adsorption of $\mathrm{Hg}^{0}$ over low-temperature $\mathrm{NH}_{3}$ SCR LaMnO 3 perovskite oxide from flue gas," Applied Catalysis B: Environmental, vol. 186, pp. 30-40, 2016. 
[15] M. Kang, E. D. Park, J. M. Kim, and J. E. Yie, "Manganese oxide catalysts for NOx reduction with $\mathrm{NH}_{3}$ at low temperatures," Applied Catalysis A: General, vol. 327, no. 2, pp. 261-269, 2007.

[16] M. Wallin, S. Forser, P. Thormählen, and M. Skoglundh, "Screening of $\mathrm{TiO}_{2}$-supported catalysts for selective $\mathrm{NO}_{x}$ reduction with ammonia," Industrial \& Engineering Chemistry Research, vol. 43, no. 24, pp. 7723-7731, 2004.

[17] G. Qi and R. T. Yang, "Performance and kinetics study for lowtemperature SCR of $\mathrm{NO}$ with $\mathrm{NH}_{3}$ over $\mathrm{MnOx}-\mathrm{CeO}_{2}$ catalyst," Journal of Catalysis, vol. 217, no. 2, pp. 434-441, 2003.

[18] W. Shan, F. Liu, Y. Yu, and H. He, "The use of ceria for the selective catalytic reduction of $\mathrm{NO}_{x}$ with $\mathrm{NH}_{3}$," Chinese Journal of Catalysis, vol. 35, no. 8, pp. 1251-1259, 2014.

[19] Z. Wu, B. Jiang, Y. Liu, W. Zhao, and B. Guan, "Experimental study on a low-temperature SCR catalyst based on $\mathrm{MnOx} / \mathrm{TiO} 2$ prepared by sol-gel method," Journal of Hazardous Materials, vol. 145, no. 3, pp. 488-494, 2007.

[20] L. Zhang, Q. Xu, J. Niu, and Z. Xia, "Role of lattice defects in catalytic activities of graphene clusters for fuel cells," Physical Chemistry Chemical Physics, vol. 17, no. 26, pp. 16733-16743, 2015.

[21] Q. Xu, Y. Lv, C. Dong et al., “Three-dimensional micro/nanoscale architectures: fabrication and applications," Nanoscale, vol. 7, no. 25, pp. 10883-10895, 2015.

[22] J. Liu, L. Yu, Z. Zhao et al., "Potassium-modified molybdenumcontaining SBA-15 catalysts for highly efficient production of acetaldehyde and ethylene by the selective oxidation of ethane," Journal of Catalysis, vol. 285, no. 1, pp. 134-144, 2012.

[23] Y. Huang, Z.-Q. Tong, B. Wu, and J.-F. Zhang, "Low temperature selective catalytic reduction of $\mathrm{NO}$ by ammonia over $\mathrm{V}_{2} \mathrm{O}_{5}$ $\mathrm{CeO}_{2} / \mathrm{TiO}_{2}$," Journal of Fuel Chemistry and Technology, vol. 36, no. 5, pp. 616-620, 2008.

[24] Y. Wang and X. Gong, "Special oleophobic and hydrophilic surfaces: approaches, mechanisms, and applications," Journal of Materials Chemistry A, vol. 5, no. 8, pp. 3759-3773, 2017.

[25] C. Zhang, D. A. Mcadams, and J. C. Grunlan, "Nano/micromanufacturing of bioinspired materials: a review of methods to mimic natural structures," Advanced Materials, vol. 28, no. 30, pp. 6292-6321, 2016. 

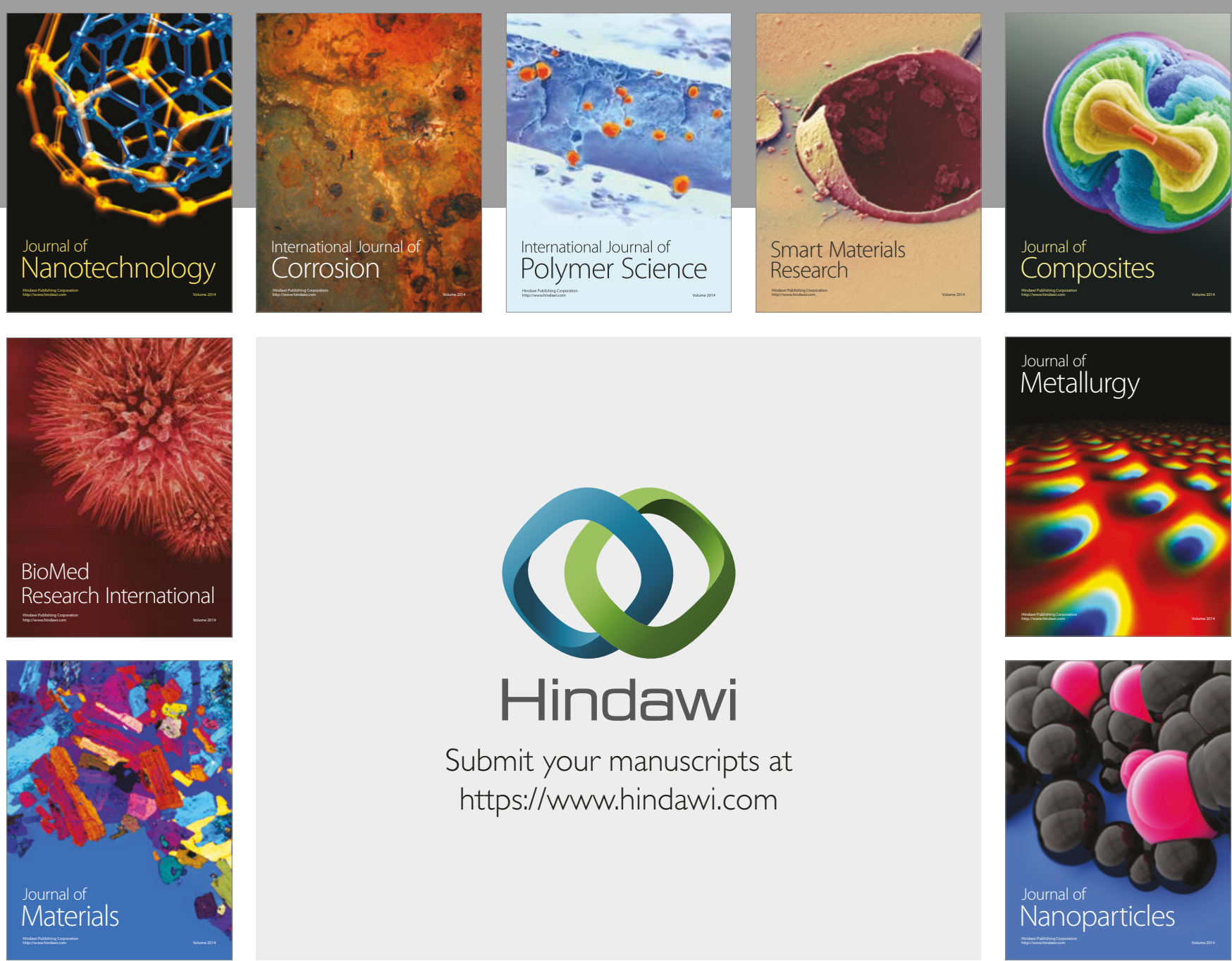

\section{Hindawi}

Submit your manuscripts at

https://www.hindawi.com
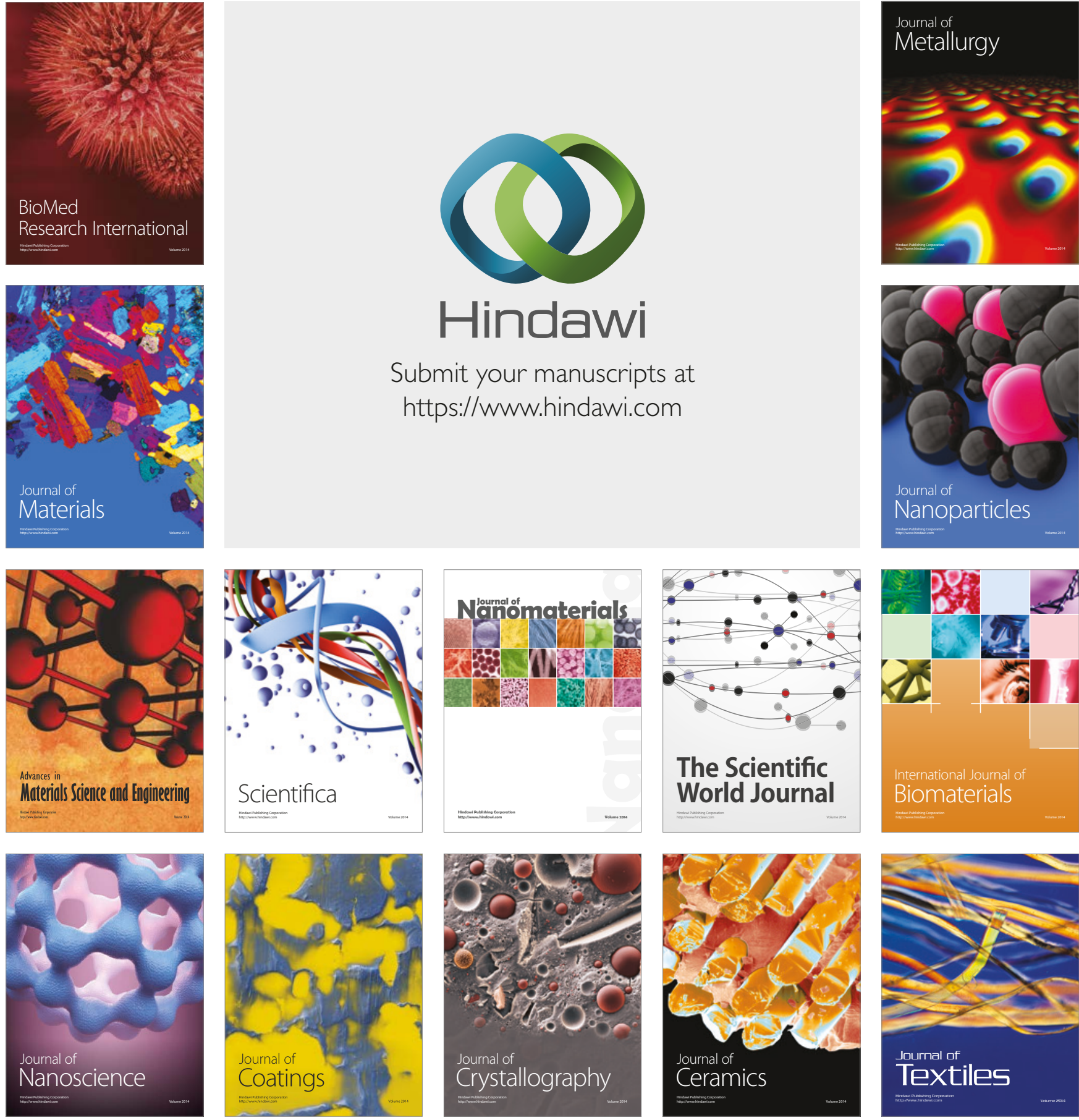

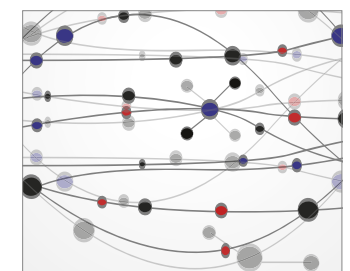

The Scientific World Journal
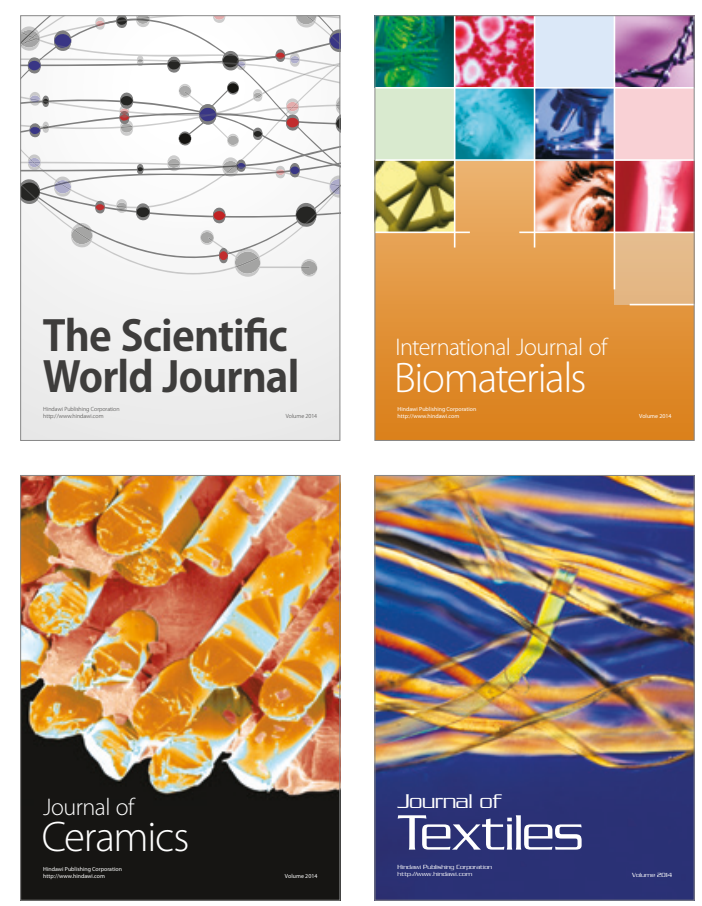